\title{
НОВЫЕ БИОТЕХНОЛОГИИ
}

\section{В АГРОПРОМЫШЛЕННОМ КОМПЛЕКСЕ}

DOI: https://doi.org/10.15688/nsr.jvolsu.2021.2.7

UDC 638.8.022.3:633.358

LBC 42.113-434

\section{PRODUCTION OF ECOLOGICALLY SAFE PRODUCTS WHEN PROCESSING PLANTS WITH A PREPARATION BASED ON BIOHUMUS}

\author{
Olga A. Zakharova \\ Ryazan State Agrotechnological University named after P.A. Kostychev, Ryazan, Russian Federation
}

Farrukh A. Musaev

Ryazan State Agrotechnological University named after P.A. Kostychev, Ryazan, Russian Federation

Mustafa G. Mustafayev

Institute of Soil Science and Agrochemistry of Azerbaijan National Academy of Science, Baku, Azerbaijan

Dmitry E. Kucher

Peoples’ Friendship University of Russia, Moscow, Russian Federation

Farid M. Mustafayev

Institute of Soil Science and Agrochemistry of Azerbaijan National Academy of Science, Baku, Azerbaijan

Abstract. Biohumus-based preparations are widespread in agricultural production due to the high content of nutrients for plants, which improve their growth and development and, as a result, productivity. GTK indicates sufficient moisture during the growing season, but, given the nature of precipitation, in certain periods, pea plants that are sensitive to moisture, experience a lack of it in the soil and atmospheric air. The research was carried out in the farm Belousov I.V. of Starozhilovsky district. The area of plots is $40 \mathrm{~m}^{2}$. Water for the preparation of the drug solution was taken from a pond located $20 \mathrm{~m}$ from the pea field. The object of the study is the seed pea (Pisumsativum), which belongs to the Fabaceae family, the genus Pisum, which forms nodules on metamorphosed roots. As a result, there is a different intensity of nutrient and water consumption in ontogenesis. Watering and spraying pea plants with Humistar preparation made it possible to reliably prove high agronomic and economic efficiency in option 2: activation of enzymes, an increase in the mass of nodules on roots to $69 \mathrm{mg} / \mathrm{plant}$, an improvement in growth to $57 \mathrm{~cm}$ and plant development by 5-15 days, an increase in peas yield up to $27,7 \mathrm{dt} / \mathrm{ha}$, accumulation of dry matter in seeds up to $59 \mathrm{~g}$ and an increase in the level of profitability up to $80,7 \%$.

Key words: biohumus, Humistar, peas, enzyme activity, mass of nodules, yield.

Citation. Zakharova O.A., Musaev F.A., Mustafayev M.G., Kucher, Mustafayev F.M. Production ofEcologically Safe Products When Processing Plants with a Preparation Based on Biohumus. Prirodnye sistemy i resursy [Natural Systems and Resources], 2021, vol. 11, no. 2, pp. 56-65. DOI: https://doi.org/10.15688/nsr.jvolsu.2021.2.7 


\title{
ПРОИЗВОДСТВО ЭКОЛОГИЧЕСКИ БЕЗОПАСНОЙ ПРОДУКЦИИ ПРИ ОБРАБОТКЕ РАСТЕНИЙ ПРЕПАРАТОМ НА ОСНОВЕ БИОГУМУСА
}

\author{
Ольга Алексеевна Захарова \\ Рязанский государственный агротехнологический университет им. П.А. Костычева, \\ г. Рязань, Российская Федерация \\ Фаррух Атауллахович Мусаев \\ Рязанский государственный агротехнологический университет им. П.А. Костычева, \\ г. Рязань, Российская Федерация \\ Мустафа Гылман Мустафаев \\ Институт почвоведения и агрохимии НАН Азербайджана, г. Баку, Азербайджан \\ Дмитрий Евгеньевич Кучер \\ Российский университет дружбы народов, г. Москва, Российская Федерация \\ Фарид Мустафа Мустафаев \\ Институт почвоведения и агрохимии НАН Азербайджана, г. Баку, Азербайджан
}

\begin{abstract}
Аннотация. Массовое внедрение в сельскохозяйственном производстве получили препараты на основе биогумуса из-за высокого содержания питательных для растений веществ, улучшающие их рост и развитие и, как следствие, повышающие урожайность. Учитывая характер выпадающих осадков в определенные периоды растения гороха, чувствительные к влаге, испытывали недостаток ее в почве и атмосферном воздухе. Исследования выполнены в КФХ Белоусов И.В. Старожиловского района. Площадь делянок $40 \mathrm{~m}^{2}$. Вода для приготовления раствора препарата бралась из пруда, расположенного в 20 м от горохового поля. Объект исследования - горох посевной (Pisumsativum), относится к семейству Fabaceae, роду Pisum, у которого на метаморфизированных корнях формируются клубеньки. Вследствие этого наблюдается разная интенсивность потребления питательных веществ и воды в онтогенезе. Поливы и опрыскивание растений гороха посевного препаратом Гумистар позволили достоверно доказать высокую агрономическую и экономическую эффективность на варианте 2: активизацию ферментов, увеличение массы клубеньков на корнях до 69 мг/ растение, улучшение роста до 57 см и развития растений на 5-15 суток, рост урожая гороха до 27,7 ц/га, накопление сухого вещества в семенах до 59 г, рост уровня рентабельности до 80,7 \%.

Ключевые слова: биогумус, Гумистар, горох, активность ферментов, масса клубеньков, урожай.
\end{abstract}

Цитирование. Захарова О. А., Мусаев Ф. А., Мустафаев М. Г., Кучер Д. Е., Мустафаев Ф. М. Производство экологически безопасной продукции при обработке растений препаратом на основе биогумуса // Природные системы и ресурсы. - 2021. - Т. 11, № 2. - С. 56-65. - DOI: https://doi.org/10.15688/nsr.jvolsu.2021.2.7

\section{Введение}

На текущее время актуальным является переработка органических отходов и рационального использования как высокоценного биологического ресурса [5; 6; 9]. В конце 1990-х гг. в странах Западной Европы и США внедрена технология вермикультивирования. Принцип ее действия состоял в использовании искусственно разведенных дождевых червей при переработке и превращении органи- ческих отходов в биологически активное, высокоэффективное удобрение [8; 9]. В России примерно в эти же годы нашли применение в практической деятельности ресурсо- и энергосберегающие биотехнологии по разведению, что позволило создать современные активнодействующие препараты. Вместе с тем на сегодняшний день в хозяйствах нашей страны они не пользуются широкой популярностью: во-первых, информация о проблемах их влияния на почву и растенияне системна, во-вторых, 


\section{НОВЫЕ БИОТЕХНОЛОГИИ В АГРОПРОМЫШЛЕННОМ КОМПЛЕКСЕ}

накопленный массив информации в виде научных статей, диссертаций, патентов до настоящего времени не обобщен, в-третьих, в практике используется малый ассортимент культур в агрономической деятельности. К тому же, в открытой печати и в сети Интернет встречается множество противоречивой информации их действия без учета конкретных почвенно-климатических условий и биологических особенностей сельскохозяйственных культур [5]. В связи со сказанным исследования по изучению влияния одного из таких препаратов на основе биогумуса, в нашем случае, Гумистара на горохе посевном в условиях неустойчивой погоды в Старожиловском районе Рязанской области являются актуальными.

По возделыванию зернобобовых Рязанская область стоит на 8-м месте в России, а по производству гороха - 6-м. По площади посевы гороха занимают в регионе 14 место, им засевается свыше $3 \%$ всех площадей, то есть более 29 тыс. га. Около 83 тыс. т зерна собирается в среднем в год. Горох посевной (Pisum sativum) принадлежит к семейству Fabaceae, роду Pisum, у которого на корнях формируются клубеньки, представляющие бактероидную ткань. Бактерии питаются минеральным азотом, что вызывает разную интенсивность потребления растениями питательных веществ в онтогенезе. Без сомнения, азот используется растениями гороха от всходов до созревания, но максимум фиксируется в фазу цветения. Фосфор в наибольшем количестве поступает в растения лишь от цветения до созревания семян при развитой симбиотической фиксации атмосферного азота. Калий в отличие от азота и фосфора интенсивнее усваивается горохом в раннем онтогенезе. Важную роль в жизнедеятельности клубеньковых бактерий играют микроэлементы, особенно молибден [2; 5]. И еще одна особенность - клубеньковые бактерии требовательны к влаге. Все биологические особенности культуры были учтены при разработке программы исследований и выборе вариантов опыта.

\section{Материалы и методика исследований}

Цель исследований, проведенных в КФХ Белоусов И.В. в Старожиловском районе Ря- занской области, изучение эффективности препарата Гумистар на горохе посевном. Научно-исследовательская работа выполнена по заявке руководителя хозяйства.

Почва хозяйства - серая лесная среднесуглинистого гранулометрического состава среднего уровня плодородия. Получить стабильно высокий урожай гороха посевного возможно только в условиях улучшения минерального питания за счет использования удобрительных средств, к примеру, препарата Гумистар, и оптимального водного режима.

Рассчитанный по общеизвестной формуле гидротермический коэффициент (ГТК) позволил определить градацию влагообеспеченности для вегетационного периода:

$$
\begin{aligned}
& \text { ГТК }=\frac{214}{0,1 \cdot 2284}=0,9 \\
& \text { - приближенный к среднемног олетним }
\end{aligned}
$$

Значение 0,9 говорит о достаточном увлажнении за вегетационный период в год исследований, но, учитывая характер выпадающих осадков в определенные периоды, растения гороха, чувствительные к влаге, испытывали недостаток ее в почве и атмосферном воздухе [6], что негативно сказывалось на росте вегетативных и развитии генеративных органов. Максимум осадков приходился на июль. В то же время дожди носили неэффективный ливневый характер, при котором большой объем воды быстро стекает вниз по профилю почвы; корни растений не успевают поглотить ее. Содержание продуктивной влаги находилось на уровне $75 \%$ от оптимума, поэтому оросительная мелиорация по-прежнему сохраняла свою актуальность. Отсюда, используемые варианты опыта способствовали не только восстановлению баланса минерального обеспечения, но и восполнению влаги в почве (поливы) и атмосферном воздухе (опрыскивание). Солнечных дней много было в начальные фазы онтогенеза, к цветению часто отмечалась облачность. В районе преобладал западный перенос воздушных масс, а в летнее время господствовали западные и северо-западные ветра. Скорость ветра изменялась значительно: от среднемноголетних значенийдо порывов 9-12 м/сек, что могло вызвать полегание стеблей, несмотря на установ- 
ленную в опыте подпорную сетку. При общем анализе погодных условий экстремальных отклонений не выявлено. В КФХ Белоусов И.В. был заложен трехфакторный мелкоделяночный полевой опыт в трехкратной повторности с вариантами, отображенными в таблице 1.

В опыте в соответствии со схемой закладывались 15 делянок общей площадью $60 \mathrm{~m}^{2}$. Технология возделывания культуры общепринятая для региона. Посев гороха в опыте проведен в конце апреля рядовым способом с нормой высева из расчета 1,2 млн семян на га.

Гумистар - концентрированная жидкая форма биогумуса, представляющая водную вытяжку гуминовых веществ и микроэлементов. Для производства препарата использовался биогумус, произведенный червями в ОАО «Агрофирма "Грин-ПИКь”». Подготовка раствора в опыте: после разведения концентрированной формы по рекомендации производителя препарат настаивался в течение 5 часов и использовался для замачивания семян перед посевом, полив 1 раз в декаду из расчета 200 мл препарата на 10 л воды и опрыскивание растений 3 раза за вегетацию из расчета 60 мл препарата на 10 л водыв соответствии с вариантами.

В полевых условиях были проведены следующие натурные и лабораторные исследования на кафедре агрономии и агротехнологии:

1. Фенологические наблюдения каждой фазы (всходы, бутонизация, начало цветения, массовой цветение, начало созревания, полное созревание).

2. Биометрические измерения при фиксировании высотырастений через каждые 7 суток начиная с фазы «полные всходы» с делянкиу 20 растений от поверхности почвы до верхнего междоузлия.

3. Формирование симбиотического аппарата определялось по массе клубеньков на корнях растений.
5. Скорость формирования листьев учитывалась у 20 растений на каждой делянке.

6. Учет урожая-поделяночно с начала цветения и до образования $30 \%$ бобов через каждые 7 суток. Для учета срезались растения с площади $1 \mathrm{~m}^{2}$ в трех точках на каждой делянке.

7. Активность каталазы фиксировалась в трехкратной повторности в фазу налива семян в листьях методом Баха и Опарина, пероксидазную активность - колориметрическим методом Бояркина с модификациями [4].

8. Динамика накопления сухих веществ в семенах гороха учитывалась только при полной спелости бобов. Из 20 растений каждой делянки обрывались бобы и из них вылущивались семена [4].

9. Для структурного анализа отбирались растения по следующим показателям: длина стебля, количество бобов, семян в бобе, семян с растения (продуктивность).

10. Определение и подсчет численности вредителей-фитофагов - по ГОСТу [1].

11. Определение сорных видов растений проводилось по ботаническому определителю и подсчет их численности [3; 7].

12. Экспериментальные данные подвергались обработке по методике Доспехова (1985) с помощью компьютерной программы Statistica 10. Усовершенствованные графические возможности программы в интерактивном приложении позволяют получить многомерные графики и настройки изображения при статистических приемах обработки результатов исследований.

Объект исследования - горох посевной интенсивного типа сорта Немчиновский 46, относящийся к среднеспелым.

\section{Результаты исследований}

Известно, антиоксидантная система растений включает ферментативные и нефер-

Таблица 1

Схема трехфакторного мелкоделяночного полевого опыта

\begin{tabular}{|c|c|c|c|}
\hline \multirow{2}{*}{$\begin{array}{c}\text { Варианты } \\
\text { опыта }\end{array}$} & \multicolumn{3}{|c|}{ Обработка препаратом Гумистар на основе биогумуса } \\
\cline { 2 - 4 } & Замачивание семян (фактор А) & Поливы (фактор Б) & Опрыскивание (фактор В) \\
\hline Контроль & нет & нет & нет \\
\hline Вариант 1 & да & нет & дет \\
\hline Вариант 2 & нет & да & да \\
\hline Вариант 3 & да & да & нет \\
\hline Вариант 4 & да & \multicolumn{2}{c|}{} \\
\hline
\end{tabular}


ментативные компоненты защиты. Пероксидаза и каталаза - важные ферменты окислительного стресса, на который реагировали растения гороха (табл. 2). В результате анализа данных таблицы 2 обнаружен предельный показатель преломления излучения Fo, падающего на слой вещества, к потоку прошедшего излучения $\mathrm{F}$, ослабленного в результате поглощения и рассеяния

$$
\mathrm{D}=\lg (\mathrm{Fo} / \mathrm{F})
$$

при определении пероксидазной активности растений на варианте 2 при поливах и опрыскивании раствором препарата. Установлены значения с отклонениями в $37,27,12$ и $9 \%$ соответственно вариантам опыта. Возрастание пероксидазной активности позволило увеличить иммунный статус, Гумистар выступил как-бы элиситором индуцированного иммунитета.

Растения смогли защититься от болезней при снижении способности поддерживать свою целостность и индивидуальность, о чем свидетельствовали результаты лабораторного опыта. Каталаза проявлялась динамичнее на варианте 2 и ее активность по сравнению с другими вариантами опыта проявилась сильнее на 117, 15 и 4 \% соответственно. Ферментативная активность у контрольных растений была в минимуме, что не могло способствовать выработке иммунитета к неблагоприятным условиям среды, поэтому и растения визуально имели невыгодный внешний вид. Достоверность результатов адекватно подтверждена статистическими уравнениями зависимости активности каталазы и пероксидазы от действующих факторов $\mathrm{R}=0,80$ и $\mathrm{R}=0,77$. Конечный результат взаимодействия растений с ризобиями слагался из степени развития симбиотического аппарата, его азотфиксирующей активности и продолжительности активного симбиоза. Созданные на варианте 2 опыта условия в мае-июне поддерживали активное развитие клубеньковых бактерий на корнях растений (см. табл. 3).

Максимальная масса клубеньков сформировалась к фазе ветвления - 22 мая - 44-69 мг/ растение, в фазу бутонизации - 5 июня-зарегистрировано угнетение процесса в виде снижения массы до 11-15 мг, а 15 июля - лизис клубеньков. На наш взгляд, большая изменчивость показателя объяснялась возделыванием гороха на участке третий год в присутствии значительной массы спонтанных штаммов ризобий.

Азотфиксация у растений гороха на варианте 2 проходила на фоне крепких проростков и достатка влаги в почве, прибавка получена по сравнению с другими вариантами опыта в фазу ветвления $57,41,33$ и $23 \%$, бутонизации $-45,33,33,5 \%$.

Продолжительность азотфиксации, по литературным источникам [3], не превышает 40 дн., а высокая температура и недостаток влаги сокращают срок до 14-20 дней. Как раз подобные погодные условия и наблюдались в ответственные периоды вегетации - июне и июле. В наших исследованиях длительность азотфиксации на вариантах 2 и 4 составляла 36 дней, на варианте 1 и 3-29 дней, на контроле - 25 дней.

Стебель гороха может расти до фазы полного созревания. В фазе 2-3 листьев высота этого вегетативного органа достигала от 3,0 до 4,5 см, а в фазе 4-5 листьев - 7,5-9,5 cм. Наиболее интенсивный рост растений гороха подмечен в фазе 6-13 листьев, то есть до цве-

Таблица 2

Ферментативная активность

\begin{tabular}{|c|c|c|c|c|c|}
\hline \multirow[b]{2}{*}{$\begin{array}{c}\text { Варианты } \\
\text { опыта }\end{array}$} & \multicolumn{3}{|c|}{$\begin{array}{c}\text { Обработка препаратом Гумистар } \\
\text { на основе биогумуса }\end{array}$} & \multicolumn{2}{|c|}{ Активность фермента } \\
\hline & $\begin{array}{c}\text { Замачи- } \\
\text { вание } \\
\text { семян }\end{array}$ & Поливы & $\begin{array}{l}\text { Опрыс- } \\
\text { кивание }\end{array}$ & $\begin{array}{c}\text { Каталаза, мкмоль } \\
\mathrm{H}_{2} \mathrm{O}_{2} / \text { г сырой массы / } \\
\text { мин } \\
\end{array}$ & $\begin{array}{c}\text { Пероксидаза, изменение } \\
\text { оптической плотности / г } \\
\text { сырой массы / мин }\end{array}$ \\
\hline Контроль & нет & нет & нет & 45 & 228 \\
\hline Вариант 1 & нет & да & нет & 100 & 246 \\
\hline Вариант 2 & нет & да & да & 98 & 312 \\
\hline Вариант 3 & да & да & да & 94 & 286 \\
\hline Вариант 4 & да & да & нет & 85 & 278 \\
\hline
\end{tabular}


тения. За период всходы-цветение прирост длины стеблей составил на варианте 2 57,2 см.

Листья гороха развивались быстро. На варианте 2 начало образования третьего листа отмечено на 5-7, четвертого - на 9-11 сутки после появления семядольных листьев. Через 3-4 суток после четвертого листа появляется пятый и еще через 3-4 суток - шестой. Формирования седьмого и восьмого листа шло через 23-25, девятого и десятого 26-30 суток после всходов. На 33-36 сутки после появления всходов было насчитано 1113 листьев. После появления 12-13 листьев наступала фаза цветения.

Продолжительность вегетации слагалась из основных периодов: посев - всходы, всходы - цветение и цветение - созревание (табл. 3).

Период посев-всходы. При обеспеченности влагой семена гороха прорастают при температуре $1-2{ }^{\circ} \mathrm{C}$, но для последующего роста уровень ее должен быть на 3-4 ${ }^{\circ} \mathrm{C}$ выше нормы. В наших опытах фаза массовых всходов наступал в среднем через 11 суток.

Период всходы-цветение колебался по вариантам опыта от 29 до 32 суток.

Для периода цветение-созревание необходимо тепло. Максимальный период (34 cу- ток) от цветения до созревания был отмечен на контроле при средней температуре воздуха в этот период $+18,0^{\circ} \mathrm{C}$, что вызвало задержку развития растений и увеличение полного вегетационного периода до 75 суток. Наиболее быстрые темпы развития растений гороха отмечены на вариантах 2 и $4-30$ суток.

Полный вегетационный период (всходы - созревание) составил на контроле 80 сут., а на варианте 2 - 65 суток, то есть на 15 сут. короче. На других вариантах -72 и 74 сут. соответственно. На наш взгляд некоторое уменьшение сроков каждого из этапа онтогенеза связано с созданием более комфортных условий для растений гороха замачиванием, поливами, опрыскиванием питательным раствором, что, в свою очередь, обеспечивало улучшение водного и питательного режимов.

Урожай являлся значимым показателем и зависел, что общеизвестно, от генетических особенностей, погодных и почвенных условий, агротехнических приемов и других причин [11]. Урожайность гороха в опыте составила 22,7-27,7 ц/га (табл. 4) и в среднем по КФХ Белоусов И.В. не превышала максимум в хороший год по погодным условиям 24 ц/га, и было выше минимума в неблагоприятные 18 ц/га.

Таблица 3

Масса клубеньков и фенологические наблюдения

\begin{tabular}{|c|c|c|c|c|c|c|}
\hline \multirow{2}{*}{$\begin{array}{c}\text { Варианты } \\
\text { опыта }\end{array}$} & \multicolumn{2}{|c|}{$\begin{array}{c}\text { Масса клубеньков } \\
\text { (фазы), г }\end{array}$} & \multicolumn{4}{|c|}{ Периоды, сут. } \\
\cline { 2 - 7 } & $\begin{array}{c}\text { Ветвле- } \\
\text { ния }\end{array}$ & $\begin{array}{c}\text { Бутони- } \\
\text { зации }\end{array}$ & $\begin{array}{c}\text { Посев- } \\
\text { всходы }\end{array}$ & $\begin{array}{c}\text { Всходы- } \\
\text { цветение }\end{array}$ & $\begin{array}{c}\text { Цветение- } \\
\text { созревание }\end{array}$ & $\begin{array}{c}\text { Всходы- } \\
\text { созревание }\end{array}$ \\
\hline Контроль & 44 & 11 & 14 & 32 & 34 & 80 \\
\hline Вариант 1 & 49 & 12 & 11 & 30 & 32 & 73 \\
\hline Вариант 2 & 69 & 16 & 9 & 28 & 28 & 65 \\
\hline Вариант 3 & 56 & 15 & 11 & 29 & 30 & 70 \\
\hline Вариант 4 & 52 & 17 & 9 & 28 & 28 & 65 \\
\hline
\end{tabular}

Таблииа 4

Урожай гороха посевного

\begin{tabular}{|c|c|c|c|c|c|}
\hline \multirow{2}{*}{ Вариант } & \multirow{2}{*}{$\begin{array}{c}\text { Урожайность } \\
\text { зерна, ц/га }\end{array}$} & \multicolumn{2}{|c|}{ Прибавка к контролю } & \multirow{2}{*}{$\begin{array}{c}\text { Ошибка } \\
\text { разности, md }\end{array}$} & \multirow{2}{*}{$\begin{array}{c}\text { Критерий } \\
\text { достоверности, } t_{\text {факт }}\end{array}$} \\
\hline & & ц/га & $\%$ & & \\
\hline Контроль & 22,7 & - & - & - & - \\
\hline Вариант 1 & 24,6 & 1,9 & 8,4 & 0,036 & $1,58^{*}$ \\
\hline Вариант 2 & 27,7 & 5,0 & 22,0 & 0,072 & 1,06 \\
\hline Вариант 3 & 25,7 & 3,0 & 13,2 & 0,133 & 1,09 \\
\hline Вариант 4 & 26,2 & 3,5 & 15,4 & 0,084 & 1,22 \\
\hline
\end{tabular}

Примечание. * - разница урожая по вариантам достоверна, так как $\mathrm{t}$ факт $>\mathrm{t}_{05}=2,4$. 
Специализированный график, интегрированный с соответствующими статистическими процедурами и доступный из диалогов и контекстных меню результирующих таблиц данных построен при проведении корреляционно-регрессионного анализа. Данный анализ, считывающий межфакторные связи, и, как следствие, определяющий роль каждого исследуемого фактора: прямое, непосредственное его влияние на результативный признак; косвенное влияние фактора через его влияние на другие факторы; влияние всех факторов на результативный признак, дал уравнение зависимости урожайности гороха $(Y)$ от активности каталазы $(a)$ и пероксидазы $(x)$, представленное в виде диаграммы на рисунке:

$$
Y=0,067+4,15 a+8,34 x .
$$

Максимальная поверхность принадлежит варианту 2, чуть ниже - варианту 4. В итоге, все графические опции и процедуры доступны из программ на Statistica Visual Basic. Урожайность зависела от числа плодоносящих растений на единицу площади и массы семян на 1 растение продуктивности. Продуктив-ность растения определлась количеством бобов на рас- тении, количеством семян в бобе и массой 1000 семян. Количество бобов на растении обусловливалось количеством продуктивных узлов и бобов на продуктивном узле. В наших опытах максимальным количеством бобов отличался вариант 2, что отображено в таблице 5.

Bсе показатели структуры урожая, по полученным данным, находились в пределах сорта. В период созревания нижних бобов накопление сухого вещества в вегетативных органах растения гороха прекращалось, а в семенах продолжалось. Из литературных данных [4] известно, что в период созревания количество азота, сахаров и крахмала в створках бобов гороха уменьшается из-за оттока этих веществ в семена. В опыте темп накопления сухого вещества в семенах гороха был различным на варианте 2 и 4 - по 59 г, белка 30,1 и $31,4 \%$ соответственно, на других вариантах было отмечено снижение показателей на 3-4 \%, что, очевидно, связано с обогащением почвы питательными веществами при поступлении с Гумистар и их усвоением растениями, и, конечно, ибо не менее важно, восполнением дефицита влаги в почве.

Одним из адаптационных факторов в получении стабильно высоких урожаев зерна

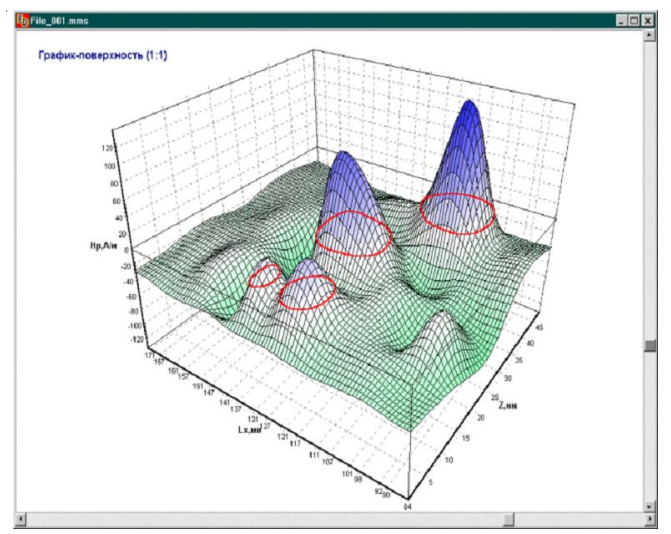

Зависимости урожайности гороха от активности каталазы и пероксидазы на вариантах опыта

Структура урожая гороха посевного

Таблииа 5

\begin{tabular}{|c|c|c|c|c|c|}
\hline \multirow{2}{*}{$\begin{array}{c}\text { Варианты } \\
\text { опыта }\end{array}$} & \multicolumn{3}{|c|}{ Количество, шт. } & \multirow{2}{*}{$\begin{array}{c}\text { Масса семян с } 1 \\
\text { растения, г }\end{array}$} & \multirow{2}{*}{$\begin{array}{c}\text { Масcа } 1000 \\
\text { семян, г }\end{array}$} \\
\hline & бобов на 1 растение & семян в бобе & семян на 1 растение & & \\
\hline Контроль & 2,3 & 3,20 & 9,58 & 1,83 & 193 \\
\hline Вариант 1 & 2,6 & 3,25 & 9,72 & 2,40 & 232 \\
\hline Вариант 2 & 3,0 & 3,65 & 9,78 & 2,49 & 243 \\
\hline Вариант 3 & 2,8 & 3,38 & 9,76 & 2,41 & 234 \\
\hline Вариант 4 & 3,0 & 3,50 & 9,76 & 2,46 & 244 \\
\hline
\end{tabular}


гороха является повреждение зерен вредителями, потери могут достичь 15-20\%. Бобовым вредят около 14 видов, из которых были изучены три вида вследствие присутствия их в наших посевах: Sitona crinitus, Laspeyresia nigricana, Acyrthosiphon pisum. Установлено, что существенного отличия в количестве фитофагов на вариантах опыта не было, но отмечено очень незначительное превышение экономического порога вредоносности $(+1 \%$ при $r=0,67)$ на всех вариантах.

Сорняки способны снижать урожайность гороха до $30 \%$. К тому же горох прорастает при температуре $+2{ }^{\circ} \mathrm{C}$, что является благоприятным условием и для сорной ранней яровой и зимующей растительности. Вначалевегетации рост растений гороха превосходит высоту сорняков, но в последующем замедляется, стебли могут полегать, что способствует вторичному заселению участка сорной растительностью. По результатам обследования видового состава сорных растений в посевах гороха выявлены в основном яровые малолетние виды Chenopodium album, Amaranthus retrofleocxus, Setaria viridis и др. Всего выделено 8 видов сорных растений из 6 семейств. По два вида найдено растений из семейств Астровые и Капустные. Несмотря на то, что Амарантовые представлены только одним видом - Amaranthus retroflexus, они занимают более $30 \%$ от общего количества сорняков на опытном участке. С учетом проведенной обработки гербицидом на основе бентазона посевов гороха, общее количество растений на $1 \mathrm{~m}^{2}$ не превышало 22 экземпляра.

При применении Гумистар теоретически обнаружена зависимость экономических показателей от способов обработки семян замачивания, поливов и опрыскивания. Расчет показал уровень рентабельности, который показал оптимальность использования препарата Гумистар на горохе посевном в хозяйстве,составил $80,7 \%$ на варианте 2 , а в контроле 58,4 \%. Рост показателя объясняется улучшением качества зерна гороха, снижением себестоимости продукции и эффективной маркетинговой стратегией хозяйства.

\section{Выводы}

Обобщая результаты исследований, достоверно доказана высокая агрономическая эффективность препарата Гумистар на горохе посевном при проведении 12 поливов при снижении влажности почвы и 3-х опрыскиваний растений на варианте 2:

- изменение оптической плотности пероксидазной активности до 312 г сырой массы в минуту; каталазная активность составила 98 мкмоль $\mathrm{H}_{2} \mathrm{O}_{2} / \Gamma$ сырой массы/мин.

- максимальная масса клубеньков сформировалась к фазе ветвления в среднем до 69 мг/растение, что выше по сравнению с другими вариантами на 17-25 мг; продолжительность азотфиксации составляла 36 дн.; высота стеблей у гороха за период всходыцветениебыла максимальной; на 33-36 сутки после появления всходов отмечено образование 11-13 листа;

- продолжительность вегетационного периода длилась 65 суток, что короче на 5-15 суток; урожай гороха составил 27,7 ц/га, что превысило средние значения по хозяйству на 15-30 \%; на 1 растение образовалось в среднем по 3 боба с 3,65 семенами массой 9 г; масса 1000 семян 243 г; накопление сухого вещества в семенах достигло 59 г;

- количество фитофагов на растениях превышало экономический порог вредоносности на $1 \%$, общее количество сорных растений на 1 м²до 22 экземпляров.

Уровень рентабельности на варианте 2 превысил в опыте $80 \%$.

\section{СПИСОК ЛИТЕРАТУРЫ}

1. Бабенко, А. И. Формирование сорных компонентов агроценоза гороха в зависимости от систем земледелия / А. И. Бабенко, С. П. Танчик. - Электрон. текстовые дан. - Режим доступа: https:// sciarticle.ru/stat.php (дата обращения: 05.08.2020). Загл. с экрана.

2. Биохимия сельскохозяйственных растений / Б. П. Плешков. - М. : Колос, 1980. - 495 с.

3. Бобков, С. В. Содержание фотосинтетических пигментов и активность ферментов окислительного стресса у диких образцов гороха / С. В. Бобков, И. А. Бычков // Земледелие. - 2018. - № 4. - С. 29-33.

4. Интегральная фитосоциологическая оценка биогумуса в условиях орошения / Ф. А. Мусаев [и др.]. - Рязань : И.П. Коняхин, 2020. - 243 с.

5. Ядовитые растения кормовых угодий и их воздействие на организм сельскохозяйственных 
животных / Ф.А. Мусаев [и др.]. - Рязань : РГАТУ, 2013. $-150 \mathrm{c}$.

6. Aigner, A. Ertragsund Anbauentwicklungbei Eiweisspflanzen in Bayern und Deutschland / A. Aigner // Tagung. - 2010. - P. 87-89.

7. Babiker, H. Effect of Feeding Different Levels of Soaked Pigeon Pea (Cajanuscajan) Seeds on Broiler Chickens Performance and Profitability/H. Babiker, K. Ahmed, A. Khadiga // Research Journal of Animal and Veterinary Sciences. - 2006. - P. 1-4.

8. Developing the Regional System of Oil Crops Production Management / D. V. Vinogradov // Research Journal of Pharmaceutical, Biological and Chemical Sciences (RJPBCS) India. - 2018. Vol. 9, № 5. - P. 1276-1284.

9. Mustafayev, M.G. Change of the Salts Quantity and Type in the Irrigated Soils of the Mughan Plain and Their Impact on Plants Productivity / M. G. Mustafayev // International Journal of the Science of Food and Agriculture. 2020. - Vol. 4, № 2. - P. 101-108.

\section{REFERENCES}

1. Babenko A.I., Tanchik S.P. Formirovaniye sornykh komponrntov agrotsenoza gorokha $v$ zavisimosti ot sistem zemledeliya [Formation of Weed Components of Pea Agrocenosis Depending on Farming Systems]. URL: https://sciarticle.ru/stat.php (accessed 5 August 2020).

2. Pleshkov B.P. Biokhimiya selskokhozyaystvennykh rasteniy [Biochemistry of Agricultural Plants]. Moscow, Kolos Publ., 1980. $495 \mathrm{p}$.
3. Bobkov S.V., Bychkov I.A. Soderzhanie fotosinteticheskih pigmentov i aktivnost fermentov okislitelnogo stressa u dikikh obraztsov gorokha [Content of Photosynthetic Pigments and Activity of Oxidative Stress Enzymes in Wild Pea Samples]. Zemledelie, 2018, pp. 29-33.

4. Musaev F.A., Byshov N.V., Borychev S.N., Zakharova O.A., et al. Integralnaya fitostsiologicheskaya otsenka biogumusa $v$ usloviyakh orosheniya [Integral Phytosociological Assessment of Biohumus in Irrigation Conditions]. Ryazan, I. P. Konyakhin, 2020. 243 p.

5. Musaev F.A., Zakharova O.A., Morozova N.I., Kostin Ya.V. Yadovitye rasteniya kormovykh ugodiy $i$ $i k h$ vozdeystviye na organizm selskokhozyaystvennykh zhivotnykh [Poisonous Plants of Forage Lands and Their Impact on the Organism of Agricultural Animals]. Ryazan, RGATU,2013.150p.

6. Aigner A. Ertragsund Anbauentwicklungbei Eiweisspflanzen in Bayern und Deutschland. Tagung, 2010, pp. 87-89.

7. Babiker H., Ahmed K., Khadiga A. Effect of Feeding Different Levels of Soaked Pigeon Pea (Cajanuscajan) Seeds on Broiler Chickens Performance and Profitability. Research Journal of Animal and Veterinary Sciences, 2006, pp. 1-4.

8. Vinogradov D.V., Konkina V.S., Kostin Y.V., et al., Developing the Regional System of Oil Crops Production Management. Research Journal of Pharmaceutical, Biological and Chemical Sciences (RJPBCS) India, 2018, vol. 9, no. 5, pp. 1276-1284.

9. Mustafayev M.G. Change of the Salts Quantity and Type in the Irrigated Soils of the Mughan Plain and Their Impact on Plants Productivity. International Journal of the Science of Food and Agriculture, 2020, vol. 4, no. 2, pp. 101-108.

\section{Information About the Authors}

Olga A. Zakharova, Doctor of Sciences (Agriculture), Professor, Ryazan State Agrotechnological University named after P.A. Kostychev, Kostycheva St, 1, 390041 Ryazan, Russian Federation, ol-zahar.ru@yandex.ru

Farrukh A. Musaev, Doctor of Sciences (Agriculture), Professor, Ryazan State Agrotechnological University named after P.A. Kostychev, Kostycheva St, 1, 390041 Ryazan, Russian Federation, farruh.musaev@mail.ru

Mustafa G. Mustafayev, Doctor of Sciences (Agriculture), Academician of the Russian Academy of Natural Science, Head of the Laboratory of Melioration Soils, Institute of Soil Science and Agrochemistry of Azerbaijan National Academy of Sciences, M. Ragima St, 5, AZ10073 Baku, Azerbaijan, meliorasiya58@mail.ru

Dmitry E. Kucher, Candidate of Sciences (Engineering), Associate Professor, Peoples' Friendship University of Russia, Miklouho-Maclaya St, 6, 117198 Moscow, Russian Federation, kucher-de@rudn.ru

Farid M. Mustafayev, Researcher, Laboratory of Melioration Soils, Institute of Soil Science and Agrochemistry of Azerbaijan National Academy of Sciences, M. Ragima St, 5, AZ10073 Baku, Azerbaijan, faridmustafayev124@gmail.com 


\section{Информация об авторах}

Ольга Алексеевна Захарова, доктор сельскохозяйственных наук, профессор кафедры агрономии и агротехнологий, Рязанский государственный агротехнологический университет им. П.А. Костычева, ул. Костычева, 1, 390041 г. Рязань, Российская Федерация, ol-zahar.ru@yandex.ru

Фаррух Атауллахович Мусаев, доктор сельскохозяйственных наук, профессор кафедры технологии производства и переработки сельскохозяйственной продукции, Рязанский государственный агротехнологический университет им. П.А. Костычева, ул. Костычева, 1, 390041 г. Рязань, Российская Федерация, farruh.musaev@mail.ru

Мустафа Гылман Мустафаев, доктор сельскохозяйственных наук, академик Российской Академии Естествознания, заведующий лабораторией мелиорации почв, Институт Почвоведения и агрохимии НАН Азербайджана, ул. М.Рагима, 5, AZ10073 г. Баку, Азербайджан, meliorasiya58@mail.ru

Дмитрий Евгеньевич Кучер, кандидат технических наук, доцент, директор научного центра исследований, комплексного проектирования и развития городского и сельского хозяйства, Российский университет дружбы народов, ул. Миклухо-Маклая, 6, 117198 г. Москва, Российская Федерация, kucher-de@rudn.ru

Фарид Мустафа Мустафаев, научный сторудник лаборатории мелиорации почв, Институт почвоведения и агрохимии НАН Азербайджана, ул. М. Рагима, 5, AZ10073 г. Баку, Азербайджан, faridmustafayev124@gmail.com 